\title{
遺伝子情報をどのように強化現場に生かすか? -JISSにおける取り組みを含めてー
}

\author{
高 橋 英 幸 $^{1}$, 大 岩 奈 青 $^{1}$, 川 原 貴 ${ }^{2}$
}

(1国立スポーツ科学センター スポーツ科学研究部, 2国立スポーツ科学センター スポーツ医学研究部)

オリンピックなどの国際レベルの競技会で活躍する トップアスリートは, 日々, 彼らの運動能力を最大限に 高めるためのトレーニングを自身のからだに課し，熾烈 な競争を勝ち抜いている。優れた指導者は選手の状態, レベルに応じてトレーニングメニューを選択し，それら のトレーニングに対する個々の応答を評価し，新たなト レーニングを導入していく，こういった意味で，強化現 場における最大の興味は, 個々の選手の運動能力を最大 限に引き出すための最も効率のよいトレーニング方法を いかに導き出すかという点にあると言える。

近年，これらトレーニングに対する応答を評価する新 しい手段として, 研究により得られた遺伝子情報の活用 が提案されている. これらの研究の内容は大きく以下の 二つに分けることができる。

1 ) 対象となる個体 (選手) のトレーニング応答の個体 差に関する研究

2）トレーニングそのものが個体（ヒト）に与える影響 について評価した研究

である，前者の研究では生まれながらに有する「遺伝」 要因に着目して, 運動能力に影響を及ぼす遺伝子多型を 探索しており，これまで約50種類の遺伝子多型が報告さ れている。後者の研究ではヒトとして有する普遍的な生 体応答に着目し, 低酸素トレーニングや加圧トレーニン グといった新しいトレーニング方法がどのような効果を もたらすのかについて, たんぱく発現の上流である「遺 伝子」発現から検討している.

これらの遺伝子情報について，強化現場ではどのよう にとらえ，取り組もうとしているのだろうか．国立ス ポーツ科学センター (JISS)におけるタレント発掘に関 する研究の一環として実施した競技団体強化スタッフを 対象としたアンケート調査では, 遺伝子研究を「推進 すべきだ」との意見が 7 割を超えていた。この結果は,
個々の選手の能力・適性に応じたトレーニング計画の立 案や, 種目適性の判断材料の一つとして遺伝子情報を活 用したいという，強化スタッフの肯定的な姿勢を反映し た結果であると言える。しかしながら，現実的には，強 化活動に遺伝子情報を活用している競技団体はほとんど ない。この原因としては，競技団体やスタッフにより考 え方に温度差があることに加えて, 遺伝子研究の成果を 強化現場で実際に利用するためには，倫理的基盤や社会 的問題, さらには遺伝子情報に対する適切な解釈等, 解 決を図らなければならない様々な課題が存在することが 挙げられる.

このような社会的背景の中で, 個人の特性を考慮して, より適した競技種目を判断したり，より効果的なトレー ニング計画を立てる上での一つの材料としてであれば, 比較的, 遺伝子情報を活用しやすいのではないかと考え られる。これまでJISSでは，低酸素トレーニングに着目 して (小規模ながら) 研究を進めてきた。低酸素トレー ニングは，高所トレーニングの代替法として発展し，最 大酸素摂取量や赤血球の増加により特に持久系パフォー マンスに有効であると考えられており，様々な競技種目 で導入されている。しかしながら，そのトレーニング効 果には大きな個人差があり, 低酸素トレーニングが我々 のからだにどのような生理的効果をもたらすかについて は不明な点も多い。 そこで，1）低酸素応答に対する個 人差に遺伝的要因が関係するか，2）低酸素トレーニン グによりどのような遺伝子発現の変化がみられるか, に ついて検討を行っている.

本シンポジウムでは, JISSにおけるプロジェクト研究 の成果も含めながら, 強化現場において遺伝子情報をど のように活用できるのか, そして, どのような課題があ るのかについて述べた。 